\title{
Analisis Sistem Human Interface (HMI) pada Kompetensi Programmable Logic Controller (PLC)
}

\author{
Angga Septian MN ${ }^{1}$, Dian Megasari ${ }^{2}$ \\ Teknik Informatika, Universitas Pamulang, Tangerang Selatan, Indonesia \\ e-mail: ${ }^{1}$ dosen01727@unpam.ac.id, ${ }^{2}$ dosen00519@unpam.ac.id
}

Submitted Date: September $11^{\text {th }}, 2020$

Revised Date: September 29 2020
Reviewed Date: September $28^{\text {th }}, 2020$

Accepted Date: September $30^{\text {th }}, 2020$

\begin{abstract}
This analysis aims to determine the difference between Human Machine Interface (HMI) based learning media and conventional learning media in influencing student competence in operating the Programmable Logic Controller (PLC). The method used was a true experimental design with a posttestonly control group design. The experimental group was given learning treatment assisted by HMI Omron with the CX-Designer software, while the control group was given treatment with conventional learning media. The treatment effect was analyzed by using different test (Mann-Whitney). The results showed that the effect of HMI-based learning media on PLC competence is as follows: (1) 61\% competence in the cognitive domain is in the very good category, 50\% competence in the affective domain is in the very good category, and $50 \%$ competence in the psychomotor domain is in the very good category; and (2) There are competency differences between HMI-based learning media and conventional learning. This is evidenced by the Sig. Count value of 0.000 in the cognitive domain, 0.000 in the affective domain, and 0.001 in the psychomotor domain, which is smaller than the Sig. Of the study of 0.05 after being given treatment.
\end{abstract}

Keywords: Programmable Logic Controller (PLC); Competence; Human Machine Interface (HMI)

\section{Abstrak}

Analisis ini bertujuan untuk mengetahui perbedaan antara media pembelajaran berbasis Human Machine Interface (HMI) dan media pembelajaran konvensional dalam mempengaruhi kompetensi mahasiswa dalam mengoperasikan Programmable Logic Controller (PLC). Metode yang digunakan adalah desain true eksperimen jenis posttest-only control group design. Grup eksperimen adalah diberikan perlakuan pembelajaran berbantuan HMI Omron dengan software $C X$-Designer, sedangkan grup kontrol diberi perlakuan media pembelajaran konvensional. Pengaruh perlakuan dianalisis dengan uji beda (MannWhitney). Hasil penelitian menunjukkan bahwa pengaruh media pembelajaran berbasis HMI terhadap kompetensi PLC adalah sebagai berikut: (1) $61 \%$ kompetensi pada ranah kognitif dalam kategori sangat baik, 50\% kompetensi pada ranah afektif dalam kategori sangat baik, dan 50\% kompetensi pada ranah psikomotorik dalam kategori sangat baik; dan (2) Terdapat perbedaan kompetensi antara media pembelajaran berbasis HMI dan pembelajaran konvensional. Hal ini dibuktikan dengan nilai Sig.hitung sebesar 0,000 pada ranah kognitif, 0,000 pada ranah afektif, dan 0,001 pada ranah psikomotorik lebih kecil dari pada Sig.penelitian sebesar 0,05 setelah diberikan perlakuan.

Kata Kunci: Programmable Logic Controller (PLC); Kompetensi; Human Machine Interface (HMI)

\section{Pendahuluan}

Kemampuan dalam menggunakan software merupakan dasar dari revolusi industri 4.0 yang menekankan pada industri berbasis Internet of Thinks (IoT). Kepala BPPI (Badan Penelitian dan Pengembangan Industri) Ngakan T.A dalam kuliah umumnya di UGM 20 Februari 2018 menyebutkan bahwa penelitian yang dilakukan pada sebagian besar industri di Jerman mengungkapkan kebutuhan pekerja akan naik sampai 96\%, khususnya di bagian R\&D dan pengembangan software (Humas Kemenperin, 2018). Pemanfaatan teknologi terbaru dan berbantuan internet menimbulkan kebutuhan akan banyaknya 
pekerjaan-pekerjaan yang baru, salah satunya yaitu pengoperasian teknologi robot untuk proses produksi di industri. Penerapan teknologi otomatisasi yang intelijen dan fleksibel sangat membantu dalam perkembangan industri manufaktur, salah satu perkembangannya yaitu pengontrolan robotika dalam dunia industri menggunakan Programmable Logic Controller (PLC). Otomatisasi industri meliputi penggunaan PLC dan mesin-mesin berbasis komputer, penggunaan teknik inspeksi otomatis, Distributed Control System (DCS), penggunaan robot, dan juga teknologi informasi.

PLC merupakan sistem elektronika yang bekerja secara digital dan perancangannya untuk kebutuhan industri (Damayanti, 2014). PLC membahas mengenai perkembangan teknologi otomatisasi, hardware, dasar logika, pemrograman, instalasi inputloutput dan sistem komunikasi. Dalam pelaksanaan penggunaan PLC, kompetensi yang diharus didapatkan yaitu dapat mengubah kasus-kasus sederhana di bidang pengontrolan menjadi suatu rangkaian logika, menulis bahasa program PLC, serta mampu melakukan pengoperasian PLC (Susanto \& Sunomo, 2017).

Berdasarkan hasil observasi terhadap peralatan praktikum di laboratorium PLC, ditemukan bahwa ketersediaan peralatan khususnya trainer PLC (peralatan simulasi PLC berbasis hardware) sangatlah terbatas, jumlahnya tidak sesuai dengan jumlah peserta didik ketika melakukan praktikum, hal ini mengakibatkan praktikum harus dilaksanakan secara bergantigantian dengan waktu yang terbatas. Terdapatnya trainer PLC yang menggunakan instalasi yang tidak sama antar trainer lainnya, sistem instalasi yang berbeda ini membuat peserta didik harus mempelajari kembali mengenai sistem instalasi tersebut yang akan waktu cukup lama untuk memahaminya.

Permasalahan di atas, berdampak pada hasil kompetensi hasil yang kurang maksimal. Pencapaian lulusan kompetensi PLC masih rendah dan membutuhkan pengayaan lebih. Dalam mengatasi permasalahan ini, maka diperlukan peralatan praktikum yang tepat dan efektif. Salah satunya adalah menggunakan media praktikum yang melibatkan keaktifan dan menuntut peran aktif peserta, yaitu dengan menerapkan simulasi berbasis HMI (Human Machine Interface) dengan berbatuan program CX-Designer dari Omron (Septian MN, 2018). HMI ini memberikan penyajian berupa gambar yang dapat dikendalikan, sehingga akan lebih mudah untuk dioperasikan/ disimulasikan dalam melakukan perancangan skema pada CX-Programmer sesuai dengan keinginan peserta (Nasir, Abbas, \& Djufri, 2019).

Penggunaan HMI ini memberikan gambaran nyata akan kinerja dan cara penggunaan alat kontrol, serta lebih mudah dalam memahami proses pengontrolan otomatis. Sistem otomasi di industri yang menggunakan PLC akan terhubung dengan HMI sebagai media pengendali dan pemantauan (Dasrill \& Risfendra, 2019). Peserta diminta untuk terlibat secara aktif dalam mengendalikan input dan output yang disediakan, sehingga dapat diketahui secara langsung mana yang berkompeten dan belum kompeten dalam mengoperasikan PLC.

\section{Metodologi Penelitian}

Penelitian ini menggunakan desain true eksperimen jenis posttest-only control group design, yaitu suatu kelompok penelitian yang diukur pasca perlakuan dengan menggunakan banyak pengukuran yang substantif (Hastjarjo, 2019). Grup eksperimen berbantuan HMI Omron dengan software CX-Designer, dan grup kontrol berbantuan media konvensional. Metode pengumpulan data yang digunakan adalah tes dan lembar observasi. Pengetesan digunakan untuk mengetahui kompetensi kognitif, sedangkan lembar observasi untuk mengetahui kompetensi afektif dan psikomotorik. Tes yang dilakukan dalam penelitian ini adalah posttest, yaitu pengetesan yang dilakukan setelah diberikannya perlakuan. Setelah dilakukan tes, maka hasil skor rerata kelas eksperimen dibandingkan dengan hasil skor rerata kelas kontrol.

\subsection{Instrumen Penelitian}

Tes untuk melihat kompetensi kogitif berupa soal-soal yang memuat indikator sesuai dengan standar kompetensi dalam merakit sistem PLC untuk keperluan industri. Indikator yang digunakan untuk menentukan tes ini menggunakan teknik penyekoran binomial, yaitu benar skornya satu (1) dan salah skornya nol (0).

Tabel 1 Indikator Kompetensi Kognitif

\begin{tabular}{|l|l|}
\hline Kompetensi & \multicolumn{1}{|c|}{ Indikator } \\
\hline Merakit & $\begin{array}{l}\text { Mampu menjelaskan fungsi komponen } \\
\text { sistem } \\
\text { kendali } \\
\text { serbasis PLC kendali berbasis PLC. }\end{array}$ \\
\cline { 2 - 2 } berbali & $\begin{array}{l}\text { Mampu merakit sistem kendali } \\
\text { berbasis PLC. }\end{array}$ \\
\hline
\end{tabular}

Kompetensi bidang afektif (sikap atau perilaku) menggunakan lembar observasi yang diambil saat peserta melakukan unjuk kerja atau 
praktikum. Indikator penilaian ini diambil berdasarkan tingkatan afektif menurut Bloom.

Tabel 2 Indikator Kompetensi Afektif

\begin{tabular}{|l|l|}
\hline \multicolumn{1}{|c|}{ Penilaian } & \multicolumn{1}{c|}{ Indikator } \\
\hline Penerimaan & Saling menghargai \\
\hline Partisipasi & Disiplin \\
\cline { 2 - 2 } & Kehadiran \\
\cline { 2 - 2 } & Keaktifan \\
\hline Penilaian sikap & Sopan santun \\
\cline { 2 - 2 } & Percaya Diri \\
\hline Organisasi & Kerjasama \\
\hline Pembentukan pola & Tanggung jawab \\
\cline { 2 - 2 } & Keselamatan kerja \\
\hline
\end{tabular}

Kompetensi bidang psikomotor merupakan penilaian yang berfokus pada keterampilan fisik seseorang atau gerak otot. Tes dalam bidang ini menggunakan lembar observasi yang mengadopsi alur kerja praktikum disaat peserta melakukan unjuk kerjanya/praktikum.

Tabel 3 Indikator Kompetensi Psikomotor

\begin{tabular}{|l|l|}
\hline \multicolumn{1}{|c|}{ Penilaian } & \multicolumn{1}{c|}{ Indikator } \\
\hline \multirow{2}{*}{$\begin{array}{l}\text { Persiapan } \\
\text { Perja }\end{array}$} & Persiapan alat dan bahan \\
\cline { 2 - 2 } & Pemeriksaan komponen \\
\cline { 2 - 2 } & Pemeriksaan alat dan bahan \\
\cline { 2 - 2 } & Pembuatan ladder diagram \\
\cline { 2 - 2 } & $\begin{array}{l}\text { Download } \text { dan } \text { transfer } \text { program } \\
\text { jumper }\end{array}$ \\
\hline Hasil Kerja & $\begin{array}{l}\text { Pengujian antara } \text { PLC dengan perangkat } \\
\text { lunak HMI }\end{array}$ \\
\cline { 2 - 2 } & $\begin{array}{l}\text { Uji coba komponen } \text { input/output dengan } \\
\text { HMI }\end{array}$ \\
\cline { 2 - 2 } & Penyelesaian tugas \\
\hline Waktu & Waktu penyelesaian praktik \\
\hline
\end{tabular}

\subsection{Pengujian Instrumen}

Pengujian tiap-tiap instrumen terdiri dari uji validitas (Corrected Item-Total Correlation), uji reliabilitas (Guttman Split-Half Coefficient) untuk tes bentuk pilihan ganda dan uji reliabilitas (Cronbach's Alpha if Item Deleted) untuk lembar observasi, serta tambahan untuk tes pilihan ganda berupa uji indeks kesukaran dan daya pembeda (Patria, Sukestiyarno, \& Rumini, 2016). Pengujian ini menggunakan bantuan program SPSS dan Microsoft Excel.

Hasil pengujian instrumen ini menunjukkan bahwa seluruh soal tes valid, nilai Corrected ItemTotal Correlation $\geq \mathrm{r}$ tabel $(0,444)$. Pada pengujian reliabilitas didapatkan nilai Guttman Split-Half Coefficient $\geq 0,80$, yang berarti butir soal tes secara keseluruhan/gabungan dinyatakan reliabel. Pada pengujian Cronbach's Alpha if Item Deleted untuk seluruh butir soal tes didapatkan $\geq 0,80$, maka disimpulkan bahwa butir-butir soal tes dinyatakan reliabel. Uji tingkat kesukaran didapatkan kategori mudah 8 soal, sedang 6 soal, dan sukar 1 soal. Uji daya beda soal didapatkan kategori cukup 2 soal, baik 10 soal, dan baik sekali 2 soal. Dapat disimpulkan bahwa seluruh instrumen dapat digunakan semuanya dalam penelitian ini.

\subsection{Pengujian Analisis}

Pengujian pada penelitian ini bertujuan untuk melihat apakah terdapat perbedaan atau tidak antara dua kelompok berdasarkan nilai means data yang tidak berkorelasi. Teknik analisis data untuk pengujian ini adalah non-parametrik, artinya tidak diperlukannya syarat data harus berdistribusi normal atau tidak. Uji analisis data non-parametrik ini menggunakan rumus dari Mann-Whitney dengan bantuan program SPSS (Azra, Nurmaliah, \& Huda, 2018).

\section{Hasil dan Pembahasan}

\subsection{Deskripsi Data}

Hasil analisis perhitungan data seluruh kompetensi pada penelitian ini adalah:

Tabel 4 Analisis Deskriptif Data Penelitian

\begin{tabular}{|c|c|c|c|c|c|c|}
\hline Kelas & $\mathbf{N}$ & Mean & $\begin{array}{c}\text { Std. } \\
\text { Dev }\end{array}$ & Min & Max & Sum \\
\hline EK & 18 & 13,67 & 1,37 & 11 & 15 & 246 \\
\hline EA & 18 & 31,67 & 2,23 & 25 & 34 & 570 \\
\hline EP & 18 & 35,52 & 2,72 & 28 & 38,5 & 639,3 \\
\hline KK & 17 & 9,82 & 3,01 & 5 & 15 & 167 \\
\hline KA & 17 & 26,65 & 3,34 & 18 & 30 & 453 \\
\hline KP & 17 & 29,28 & 5,668 & 20,7 & 37,3 & 497,7 \\
\hline
\end{tabular}

Keterangan:

EK : Kelas Eksperimen Kompetensi Kognitif EA : Kelas Eksperimen Kompetensi Afektif EP : Kelas Eksperimen Kompetensi Psikomotor

KK : Kelas Eksperimen Kompetensi Kognitif KA : Kelas Eksperimen Kompetensi Afektif KP : Kelas Eksperimen Kompetensi Psikomotor 


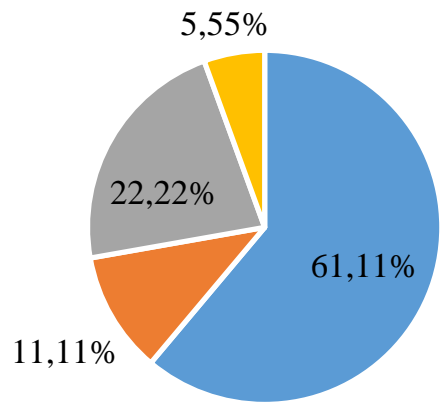

- Sangat Baik

- Baik

- Cukup

Kurang

Gambar 1. Kategori Skor Kelas EK

Skor kelas eksperimen pada kompetensi kognitif dengan frekuensi terkecil terdapat pada kategori "kurang" yaitu sebanyak 1 responden atau $5,56 \%$, sedangkan skor dengan frekuensi terbesar pada kategori "sangat baik" yaitu sebanyak 11 responden atau $61,11 \%$.

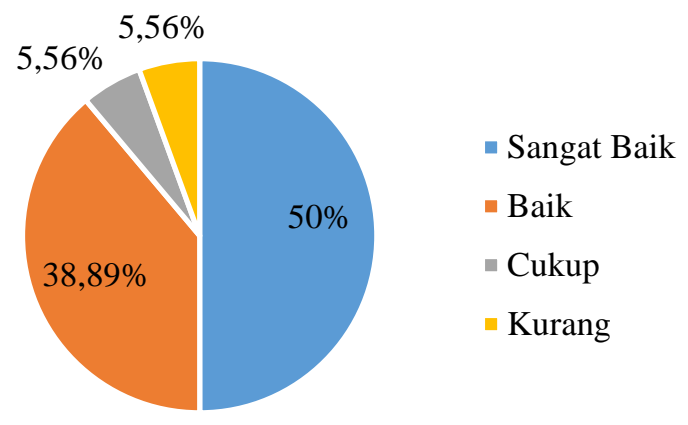

Gambar 2. Kategori Skor Kelas EA

Skor kelas eksperimen kompetensi afektif dengan frekuensi terkecil terdapat pada kategori "cukup" dan "kurang" masing-masing sebanyak 1 responden atau $5,56 \%$, sedangkan skor dengan frekuensi terbesar pada kategori "sangat baik" yaitu sebanyak 9 responden atau 50,00\%.

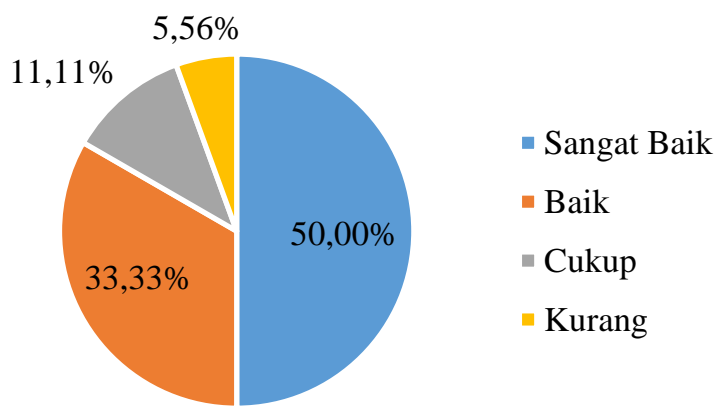

Gambar 3. Kategori Skor Kelas EP
Skor kelas eksperimen kompetensi psikomotor dengan frekuensi terkecil terdapat pada kategori "kurang" yaitu sebanyak 1 responden atau $5,56 \%$, sedangkan skor dengan frekuensi terbesar pada kategori "sangat baik" yaitu sebanyak 9 responden atau $50,00 \%$.

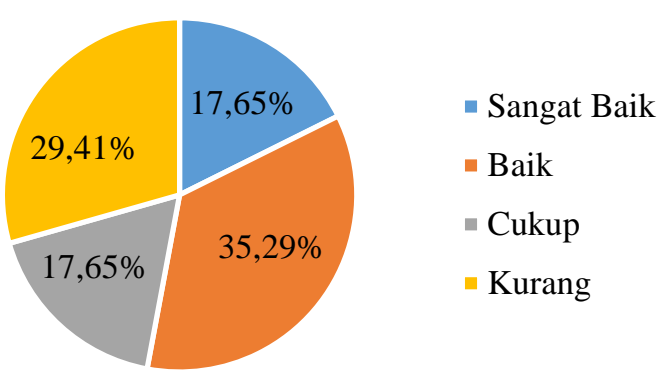

Gambar 4. Kategori Skor Kelas KK

Skor kelas kontrol kompetensi kognitif dengan frekuensi terkecil terdapat pada kategori sangat "baik" dan "cukup" yaitu masing-masing sebanyak 3 responden atau $17,65 \%$, sedangkan skor dengan frekuensi terbesar pada kategori "baik" yaitu sebanyak 6 responden atau 35,29\%.

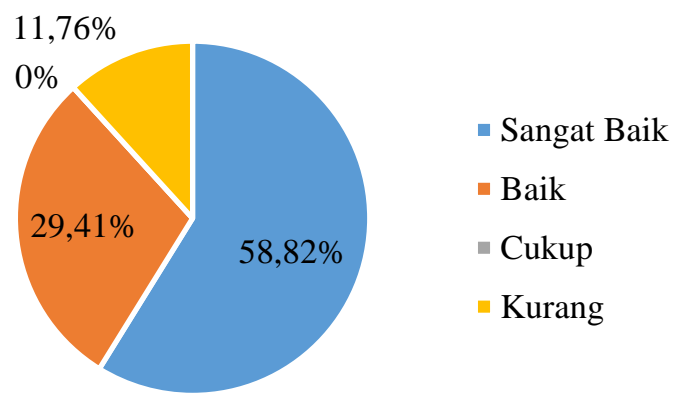

Gambar 5. Kategori Skor Kelas KA

Skor kelas kontrol kompetensi afektif dengan frekuensi terkecil terdapat pada kategori "cukup" yaitu sebanyak 0 responden atau $0,00 \%$, sedangkan skor dengan frekuensi terbesar pada kategori "sangat baik" yaitu sebanyak 10 responden atau $58,82 \%$. 


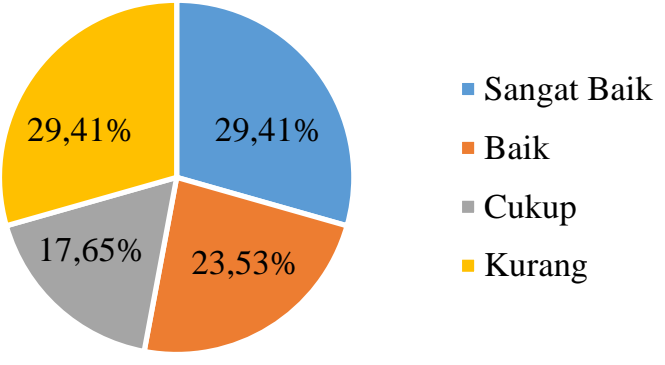

Gambar 6. Kategori Skor Kelas KP

Skor kelas kontrol kompetensi psikomotor dengan frekuensi terkecil terdapat pada kategori "cukup" yaitu sebanyak 3 responden atau 17,65\%, sedangkan skor dengan frekuensi terbesar pada kategori "sangat baik" dan "kurang" yaitu masingmasing sebanyak 5 responden atau $29,41 \%$.

\subsection{Analisis Data Penelitian}

Perhitungan analisis data pada penelitian ini menggunakan bantuan program SPSS. Pengujian kompetensi pada kelas ekperimen dan kontrol dengan uji statistik non-parametrik (MannWhitney) pada dua sampel kelompok independen.

Tabel 5. Analisis Data Penelitian

\begin{tabular}{|l|r|r|r|}
\hline & Kognitif & Afektif & Psikomotor \\
\hline $\begin{array}{l}\text { Mann- } \\
\text { Whitney U }\end{array}$ & 39,500 & 19,000 & 49,500 \\
\hline $\begin{array}{l}\text { Asymp. Sig. } \\
\text { (2-tailed) }\end{array}$ & 0,000 & 0,000 & 0,001 \\
\hline
\end{tabular}

Berdasarkan hasil output program SPSS didapatkan hasil tes statistik uji Mann-Whitney dengan nilai (2-tailed) sebesar 0,000 (kognitif), 0,000 (afektif), dan 0,001 (psikomotor) yang lebih rendah dari nilai probabilitas yaitu sebesar 0,05 . Dapat disimpulkan bahwa ada perbedaan yang signifikan antara media HMI dan media konvensional dalam mempengaruhi kompetensi merakit sistem PLC untuk keperluan industri.

Terdapatnya perbedaan yang signifikan antara kelas ekperimen dan kontrol pada kompetensi ranah kognitif, afektif, dan psikomotorik, membuktikan adanya perbedaan antara penerapan media HMI dan media konvensional dalam mempengaruhi kompetensi PLC. Penggunaan media berbasis HMI terdapat hambatan yang dialami oleh peneliti, seperti masih ada peserta yang merasa bimbang terhadap apa yang harus dilakukan ketika awal mula praktikum. Hal ini disebabkan mahasiswa sudah awam dengan media dan proses yang konvensional dan butuh penyesuaian diawal-awal waktu. Disaat dalam penanganan persoalan kerap terjadi perbedaan konsep, tetapi keadaan tersebut dapat teratasi dengan menggali pemahaman yang sudah dimiliki dan menghubungkan dengan konsep-konsep dasar yang sudah ada dalam memecahkan masalah. Peserta di kelas eksperimen diketahui lebih tangkas serta bersungguh-sungguh dalam melakukan kegiatan praktikum. Hal ini menunjukkan bahwa media HMI dapat mengembangkan aktivitas belajar peserta secara berkelanjutan, serta meningkatkan minat dan motivasi belajar meskipun batas waktu yang diberikan sudah selesai.

\section{Kesimpulan}

Simpulan dari hasil penelitian ini adalah sebagai berikut:

1. Sebagian besar $61 \%$ nilai kompetensi kognitif dalam kategori "sangat baik", $50 \%$ nilai kompetensi afektif dalam kategori "sangat baik", dan 50\% nilai kompetensi psikomotor dalam kategori "sangat baik".

2. Ada perbedaan kompetensi yang signifikan antara media HMI dan media konvensional yang dibuktikan dengan nilai Sig.hitung $\leq$ Sig.penelitian setelah pemberian perlakuan.

\section{Saran}

Pemilihan media HMI penting disesuaikan dengan pelajaran yang akan diberikan, hal ini dilakukan karena media pengajaran tidak akan selalu sesuai dengan pembelajaran yang lainnya. Kondisi ini dapat memnerikan petunjuk yang lebih riil kepada peserta, serta akan lebih menggali motivasi dan minat peserta menjadi lebih baik. Media HMI untuk selanjutnya agar dapat menggunakan sumber media yang lebih menarik, dengan mengedepankan teknologi terkini yang bersesuaian dengan perkembangan industri saat ini.

\section{Referensi}

Azra, U., Nurmaliah, C., \& Huda, I. (2018, April). Perbedaan Hasil Belajar Siswa Pada Materi Sistem Pernapasan Dengan Menggunakan Media Audio Visual di Pesantren Modern kota Banda Aceh. Jurnal EduBio Tropika, hal. 4955.

Damayanti, E. (2014). Rancang Bangun Pengendali Otomatis Pada Mesin Oil Separator Berbasis PLC (Programmable Logic Controller). Jurnal TEDC, 225-231.

Dasrill, A., \& Risfendra. (2019, Februari). Perancangan Human Machine Interface Untuk Sistem 
Otomatis Storage Berbasis PLC. Jurnal Teknik Elektro dan Vokasional, hal. 1-6.

Hastjarjo, T. (2019). Rancangan Eksperimen-Kuasi (Quasi-Experimental Design). Buletin Psikologi, hal. 187-203.

Humas Kemenperin. (2018, Februari 20). Kepala BPPI memberikan Kuliah Umum di Fak Tehnik UGM. Diambil kembali dari kemenperin.go.id: https://kemenperin.go.id/artikel/18839/Kepala -BPPI-memberikan-Kuliah-Umum-di-FakTehnik-UGM

Nasir, M., Abbas, M., \& Djufri, I. (2019, Mei). Perancangan Simulator Programmable Logic Controller (PLC) untuk Praktikum. Jurnal PROtek (Jurnal Ilmiah Teknik Elektro), hal. 4852.
Patria, L., Sukestiyarno, \& Rumini. (2016). Instrumen Penilaian Lompat Jauh Berbasis Rolling Assessment Dalam Pembelajaran Penjasorkes SMP. Journal of Educational Research and Evaluation, hal. 21-31.

Septian MN, A. (2018). Penerapan Trainer Human Machine Interface (HMI) Berbasis CXDesigner Sebagai Media Pembelajaran Programmable Logic Controller (PLC). Jurnal Informatika Universitas Pamulang, 27-33.

Susanto, A., \& Sunomo. (2017, November). Modul Programmable Logic Controller (PLC) Berbasis Arduino Severino. Jurnal edukasi Elektro, hal. 99-109. 